\title{
The effect of influenza vaccine on cytokine production by human mononuclear cells
}

\author{
Hanna Bessler* and Meir Djaldetti \\ Laboratory for Immunology and Hematology Research, Rabin Medical Center - Hasharon Hospital, Petah-Tiqva, and the Sackler School of Medicine, Tel-Aviv \\ University, Ramat-Aviv, Israel
}

\begin{abstract}
Background: Seasonal influenza outbursts present a considerable challenge for health providers. Therefore, great efforts are made to vaccinate as many individuals as possible to avoid loss of labor days, unnecessary admissions and complications. The vaccine used in our country during the $2014-2015$ seasons contains the following influenza strains, i.e., A/California (H1N1), A/Texas (H3N2) and B/Massachusetts. Vaccinated people react by mobilizing all components of the immune system. The aim of the study was to examine the vaccine effect on human peripheral blood mononuclear cells (PBMC) activation and their capacity for inflammatory cytokine production.

Methods: PBMC were incubated for 24 hrs without or with lipopolysaccharide or for 48 hrs with phorbol meristate acetate and ionomycin to determine the secretion of TNF- $\alpha$, IL-1 $\beta$, IL-6, IL-1ra and IL-10, IL-2 and IFN- $\gamma$ by non-stimulated or stimulated PBMC. Influenza vaccine was added at the onset of cultures at the following concentrations: $0.08 \mu \mathrm{l} / \mathrm{ml}, 0.2 \mu \mathrm{l} / \mathrm{ml}$ and $0.5 \mu \mathrm{l} / \mathrm{ml}$.

Results: Incubation of non-stimulated PBMC with influenza vaccine caused a marked increase in IL-2 and IFN- $\gamma$ production. The secretion of the other pro- and anti-inflammatory cytokines tested was not affected by incubation with the vaccine.

Conclusions: Considering the increased production of IL-2 and IFN- $\gamma$ following incubation of PBMC with influenza vaccine viruses and the central role of these cytokines as stimulators of cellular and humoral activity, $\mathrm{T}$ and NK cell proliferation, and as promoters of macrophages to kill phagocytized pathogens, efforts should be made to vaccinate as many individuals as possible to prevent influenza spreading.
\end{abstract}

\section{Condensed abstract}

The vaccine against influenza used in our country during the 20142015 seasons contains the following strains: A/California (H1N1), A/Texas (H3N2) and B/Massachusetts. The study was designed to examine the vaccine effect on capacity for cytokine production by human peripheral blood mononuclear cells (PBMC). PBMC were incubated with influenza vaccine and the secretion of TNF- $\alpha$, IL- $1 \beta$, IL-6, IL-1ra, IL-10, IL-2 and IFN- $\gamma$ was examined. Influenza vaccine caused a marked increase in IL-2 and IFN- $\gamma$ production. Since these cytokines act as stimulators of cellular and humoral activity, efforts should be made to vaccinate as many individuals as possible to prevent influenza spreading.

\section{Introduction}

Seasonal outbursts of influenza are associated with considerable health risks terminating with comorbidity and even mortality. According to Laidlaw et al., [1] influenza virus epidemics are the cause of about 36,000 annual deaths in the United States. Needless to say therefore, that these influenza epidemics present a serious therapeutic and financial burden to health providers. Since older individuals, immune-compromised and immunosuppressed patients are easy targets to viral invasions, health insurance establishments make great efforts to protect as many individuals as possible by vaccination with inactivated influenza viruses. It is notable that following influenza virus invasion the organism mobilizes various arms of its immune defenses, such as production of specific antibodies, macrophages stimulated for cytokine production, as well as activation of influenza virus specific $\mathrm{T}$ cells in order to protect it. It has been shown that a combination between $\mathrm{CD}^{+} \mathrm{T}$ cells with influenza virus-specific non-neutralizing antibodies provides solid protective immunity [1]. Similarly, virus-specific $\mathrm{CD} 4^{+} \mathrm{T}$ cells, not only exert a direct cytotoxic effect, but also provide help to $\mathrm{CD}^{+} \mathrm{T}$ cells $[2,3]$. The protective role of the peripheral blood mononuclear cells (PBMC) against influenza viral infections merits attention. The interactions between these cells and influenza viruses triggers several functions such as chemotaxis, phagocytosis, enzyme synthesis, activation of toll-like receptors, inflammatory cytokine generation, to cite a few of them [4-7]. Due to repeated exposure to influenza virus infections, the organism develops strain-specific antibodies that react against circulating viruses which consequently endure antigenic mutations [3]. While the inflammatory response is not a prerogative to immune cells only, it has been reported that these cells, challenged with influenza A virus infections, react by an intensive production of a lengthy list of chemokines and cytokines including TNF- $\alpha$, IL- $1 \beta$, IL- 6 , IL- 18 and IFN- $\alpha / \beta$, a capacity lesser pronounced by respiratory epithelial cells $[8,9]$. Exposure of human macrophages to influenza virus resulted in a marked production of

Correspondence to: Hanna Bessler, Laboratory for Immunology and Hematology Research, Rabin Medical Center, Hasharon Hospital, 7, Keren Kayemet St, Petah Tiqva, Israel, Tel: 972-3-9372480; Fax: 972-3-9372388; E-mail: hannab@clalit.org.Il

Key words: influenza vaccine, immunity, mononuclear cells, cytokines

Received: November 05, 2016; Accepted: December 02, 2016; Published: December 06, 2016 
IL-1 but not of IL-2 [10]. Similar observations have been reported following influenza vaccination. Mohanty et al. [11] have reported that the immune response of $\mathrm{CD} 14^{+}$and $\mathrm{CD}_{1} 6^{+}$monocytes from young and older adults, expressed by TNF- $\alpha$, IL- 6 and IL- 10 production was markedly stimulated following influenza vaccination. The query put forward in the present study was to evaluate the capacity of PBMC for cytokine production following incubation with influenza vaccine in vitro, as a way to prevent the effect of additional potential factors operating in vivo after influenza vaccination. Israeli Health Authorities have advised use of influenza vaccine containing three viral strains i.e. A/California (H1N1), A/Texas (H3N2) and B/Massachusetts for deterrence of a possible seasonal 2014-2015 outbreak. Therefore, it was decided to use vaccine with these subtypes of influenza viruses in the present study.

\section{Materials and methods}

\section{Cell preparation and culture conditions}

Peripheral blood mononuclear cells (PBMC) were separated from venous blood of adult donors ( $n=20$, aged $49.3 \pm 6.7$ years) by gradient centrifugation using Lymphoprep-1077 (Axis-Shield PoC AS, Oslo, Norway). The cells were washed twice in phosphate buffered saline (PBS) and suspended in RPMI-1640 medium (Biological Industries, Beith Haemek, Israel) containing $1 \%$ penicillin, streptomycin and nystatin and supplemented with $10 \%$ fetal calf serum (designated as complete medium CM).

\section{Influenza vaccine}

Influenza vaccine - Fluarix (split virion, inactivated GlaxoSmith Biologicals, Branch of SB Pharma GmbH \& Co. KG, Dresden, Germany) containing antigens equivalent to the following subtypes: A/California/7/2009 (H1N1) pdm09-like strain, A/Texas/50/2012 (H3N2)-like strain, B/Massachusetts/02/2012-like strain. This vaccine complies with the WHO recommended strains (Northern Hemisphere) for the season 2014/2015. Each $0.5 \mathrm{ml}$ vaccine contains $15 \mu \mathrm{g}$ hemagglutinin of each of the recommended strains.

\section{Effect of influenza vaccine on cytokine production}

$2 \times 10^{6} / \mathrm{ml}$ of PBMC suspended in CM were incubated in 24 well plates ((Nunc, Roskidle, Denmark) for 24 hrs without or with $20 \mathrm{ng} / \mathrm{ml}$ lipopolysaccharide (LPS, E. coli, Sigma) to determine the secretion of TNF- $\alpha$, IL- $1 \beta$, IL- 6 , IL-1ra and IL-10 by non-stimulated or stimulated PBMC. Cells were incubated for $48 \mathrm{hrs}$ without or with $1 \mu \mathrm{g} / \mathrm{ml}$ of phorbol meristate acetate (PMA-Sigma, Israel) and $0.5 \mu \mathrm{g} / \mathrm{ml}$ of ionomycin (Sigma, Israel) to evaluate the spontaneous or stimulated production of IL- 2 and IFN- $\gamma$. Influenza vaccine was added at the onset of cultures at the following concentrations: $0.08 \mu \mathrm{l} / \mathrm{ml}, 0.2 \mu \mathrm{l} / \mathrm{ml}$ and $0.5 \mu \mathrm{l} / \mathrm{ml}$.
The plates were incubated at $37^{\circ} \mathrm{C}$ in a humidified atmosphere supplemented with $5 \% \mathrm{CO}_{2}$. At the end of the incubation period, the cells were removed by centrifugation and the supernatants were kept at $-70^{\circ} \mathrm{C}$ until assayed for cytokine content.

\section{Cytokine content in the supernatants}

The concentration of cytokines in the supernatants was tested using ELISA kits specific for human cytokines (Biosource International, Camarillo, CA) as detailed in the manufacturer's guide-line. Each kit is specific for one individual cytokine. The detection level of cytokines in each one of the kits was $30 \mathrm{pg} / \mathrm{ml}$.

\section{Statistical analysis}

Data was analyzed using one way ANOVA with repeated measures to analyze the effect of influenza vaccine various concentrations on each cytokine secretion and two tailed paired Student's t-test to compare between cytokine secretion with each dose of the vaccine with that of the control. The results are expressed as mean \pm SEM. P value $<0.05$ was considered as statistically significant.

\section{Results}

\section{Effect of influenza vaccine on pro-inflammatory cytokine production}

Table 1 shows that incubation of either non-stimulated or LPS stimulated PBMC with the three concentrations of influenza vaccine, had no significant effect on the production of TNF- $\alpha(F 3,63=0.012$, $\mathrm{p}=0.99$ or $\mathrm{F} 3,43=0.668, \mathrm{p}=0.58$, respectively), IL- $\beta \quad(\mathrm{F} 3,47=0.298$, $\mathrm{p}=0.826$ or $\mathrm{F} 3,63=0.717, \mathrm{p}=0.55$, respectively) or IL- $6(\mathrm{~F} 3,47=0.043$, $\mathrm{p}=0.99$ or $\mathrm{F} 3,47=0.701, \mathrm{p}=0.56$, respectively). However, $5 \mu \mathrm{l} / \mathrm{ml}$ influenza vaccine caused $17 \%$ reduction in the secretion of IL- $1 \beta$ induced by LPS being statistically significant $(\mathrm{p}=0.0006)$ (Table 1$)$.

\section{Effect of influenza vaccine on anti-inflammatory cytokine production}

The production of the anti-inflammatory cytokines IL-10 and IL1ra by non-stimulated or LPS stimulated PBMC was not affected by the addition of influenza vaccine at the three concentrations used in the study $(\mathrm{F} 3,43=0.774, \mathrm{p}=0.515$ or $\mathrm{F} 3,43=0.205, \mathrm{p}=0.89$, respectively) for IL-10 and $(\mathrm{F} 3,43=0.638, \mathrm{p}=0.594$ or $\mathrm{F} 3,43=0.219 \mathrm{p}=0.882$ respectively) for IL-1ra, (Table 1).

\section{Effect of influenza vaccine on IL- 2 and IFN- $\gamma$ production}

A dose-dependent stimulation of IL- 2 or IFN- $\gamma$ generation was found when non-stimulated PBMC were incubated with increased concentrations of influenza vaccine between $0.08-0.5 \mu \mathrm{l} / \mathrm{ml}(\mathrm{F} 3,55=3.8$, $\mathrm{p}=0.015$ or $\mathrm{F} 3,55=3.35, \mathrm{p}=0.025$, respectively) (Table 2 , Figure 1 ). Incubation of PMA/ionomycine stimulated PBMC with the same

Table 1. Effect of influenza vaccine on pro- and anti-inflammatory cytokine secretion.

\begin{tabular}{|c|c|c|c|c|c|c|c|c|c|c|}
\hline \multirow[b]{3}{*}{ Influenza vaccine } & \multicolumn{6}{|c|}{ Pro-inflammatory Cytokines } & \multicolumn{4}{|c|}{ Anti-inflammatory Cytokines } \\
\hline & \multicolumn{2}{|c|}{ TNF- $\alpha$, ng/ml } & \multicolumn{2}{|c|}{ IL-1ß, ng/ml } & \multicolumn{2}{|c|}{ IL-6, ng/ml } & \multicolumn{2}{|c|}{ IL-10, ng/ml } & \multicolumn{2}{|c|}{ IL-1ra, ng/ml } \\
\hline & Spon $n=20$ & LPS $n=12$ & Spon $n=12$ & LPS $n=16$ & Spon $n=12$ & LPS $n=12$ & Spon $\mathrm{n}=12$ & LPS $n=12$ & Spon $n=12$ & LPS $n=12$ \\
\hline 0 & $0.31 \pm 0.03$ & $1.0 \pm 0.1$ & $1.6 \pm 0.1$ & $5.5 \pm 0.6$ & $11.4 \pm 1.8$ & $38.1 \pm 3.6$ & $0.33 \pm 0.03$ & $1.5 \pm 0.2$ & $0.73 \pm 0.04$ & $0.95 \pm 0.03$ \\
\hline $0.08 \mu \mathrm{l} / \mathrm{ml}$ & $0.33 \pm 0.03$ & $0.9 \pm 0.1$ & $1.6 \pm 0.2$ & $5.2 \pm 0.5$ & $12.3 \pm 1.9$ & $37.0 \pm 3.5$ & $0.42 \pm 0.06$ & $1.3 \pm 0.1$ & $0.79 \pm 0.04$ & $0.98 \pm 0.04$ \\
\hline $0.2 \mu \mathrm{l} / \mathrm{ml}$ & $0.32 \pm 0.04$ & $1.0 \pm 0.1$ & $1.7 \pm 0.1$ & $4.9 \pm 0.6$ & $11.8 \pm 1.9$ & $36.2 \pm 3.0$ & $0.43 \pm 0.04$ & $1.4 \pm 0.2$ & $0.07 \pm 0.04$ & $0.96 \pm 0.08$ \\
\hline $0.5 \mu \mathrm{l} / \mathrm{ml}$ & $0.35 \pm 0.04$ & $1.0 \pm 0.1$ & $1.5 \pm 0.2$ & $4.6 \pm 0.6^{*}$ & $11.8 \pm 1.3$ & $37.3 \pm 2.8$ & $0.44 \pm 0.07$ & $1.5 \pm 0.1$ & $0.82 \pm 0.06$ & $0.92 \pm 0.05$ \\
\hline
\end{tabular}

Effect of influenza vaccine on the secretion of inflammatory cytokines by non-stimulated (spontaneous), or LPS-stimulated PBMC. $2 \times 106$ PBMC were incubated for 24 hrs in the absence (0) or presence of influenza vaccine at concentrations as indicated. The level of the cytokines in the supernatant was tested by ELISA.

Spont. - spontaneous cytokine production by non-stimulated cells. LPS -lipopolysaccharide stimulated cells. *p=0.0006 
concentrations of influenza vaccine had no significant effect on either IL-2 production $(\mathrm{F} 3,47=2.05, \mathrm{p}=0.104)$ or $\mathrm{IFN}-\gamma$ secretion $(\mathrm{F} 3,47=0.78$, $\mathrm{p}=0.512$, Table 2). At vaccine concentrations of $0.08,0.2$ and $0.5 \mu \mathrm{l} /$ $\mathrm{ml}$ the spontaneous secretion of IL-2 was enhanced by $20 \%, 45 \%$ and by $75 \%(\mathrm{p}>0.05, \mathrm{p}<0.01, \mathrm{p}<0.001$ respectively) and that of spontaneous production of IFN- $\gamma$ by $160 \%, 240 \%$ and $340 \%(\mathrm{p}<0.01, \mathrm{p}<0.05, \mathrm{p}<0.01$ respectively).

\section{Discussion}

Human peripheral blood monocytes unrelatedly of their phenotype react vividly following contact with influenza or other viruses [12]. These cells were found to be increased in numbers in $90 \%$ of all patients with probable influenza, with or without concomitant lymphopenia [13]. It has been reported that there is a rapid differentiation of monocytes to interferon producing myeloid dendritic cells following influenza virus infection [14]. Similar results have been obtained by Hou et al., [15] who have achieved a differentiation of human monocytes to dendritic cells after 18 hours of their contact with influenza and other viruses. The results of the present study indicate that interaction between peripheral blood mononuclear cells and the influenza vaccine did not activate both non-stimulated and LPS-stimulated cells for TNF- $\alpha$, IL- $1 \beta$ and IL-6 production. Similar results were observed when the production of the anti-inflammatory cytokines IL-10 and IL-1ra by PBMC was evaluated. On the other hand, the results depicted a clear stimulatory effect of the influenza viruses on IL- 2 and IFN- $\gamma$ levels produced by the

Table 2. Effect of Influenza vaccine on IL-2 and IFN- $\gamma$ secretion.

\begin{tabular}{|c|c|c|c|c|}
\hline Cytokine & \multicolumn{2}{|c|}{ IL-2, ng/ml } & \multicolumn{2}{c|}{ IFN- $\gamma, \mathbf{n g} / \mathbf{m l}$} \\
\hline $\begin{array}{c}\text { Influenza } \\
\text { vaccine }\end{array}$ & $\begin{array}{c}\text { Spont. } \\
\mathrm{n}=14\end{array}$ & $\begin{array}{c}\text { PMA/iono } \\
\mathrm{n}=12\end{array}$ & $\begin{array}{c}\text { Spont. } \\
\mathrm{n}=14\end{array}$ & $\begin{array}{c}\text { PMA/iono } \\
\mathrm{n}=12\end{array}$ \\
\hline 0 & $0.29 \pm 0.02$ & $23.7 \pm 1.9$ & $0.37 \pm 0.05$ & $33.6 \pm 2.2$ \\
\hline $0.08 \mu 1 / \mathrm{ml}$ & $0.35 \pm 0.04$ & $20.9 \pm 1.9$ & $0.97 \pm 0.25^{*}$ & $32.1 \pm 2.9$ \\
\hline $0.2 \mu 1 / \mathrm{ml}$ & $0.42 \pm 0.05^{* *}$ & $18.0 \pm 2.4$ & $1.26 \pm 0.31^{*}$ & $31.8 \pm 2.0$ \\
\hline $0.5 \mu 1 / \mathrm{ml}$ & $0.51 \pm 0.06^{* * *}$ & $20.6 \pm 2.1$ & $1.63 \pm 0.41^{* *}$ & $34.0 \pm 2.2$ \\
\hline
\end{tabular}

Effect of influenza vaccine on the production of IL- 2 and IFN- $\gamma$ by non-stimulated or PMA/ ionomycin -stimulated PBMC. $2 \times 106$ PBMC were incubated for $48 \mathrm{hrs}$ in the absence $(0)$ or presence of influenza vaccine at concentrations as indicated. The level of the cytokines in the supernatant was tested by ELISA. Asterisks represent statistically significant difference from cells incubated without influenza vaccine $\left({ }^{*} \mathrm{p}<0.05 ; * * \mathrm{p}<0.01 ; * * * \mathrm{p}<0.001\right)$.

Spont. - spontaneous cytokine production by non-stimulated cells.

PMA/iono (phorbol meristate acetate) stimulated cells. ${ }^{*} \mathrm{p}<0.05,{ }^{* *} \mathrm{p}<0.01,{ }^{* * *} \mathrm{p}<0.001$

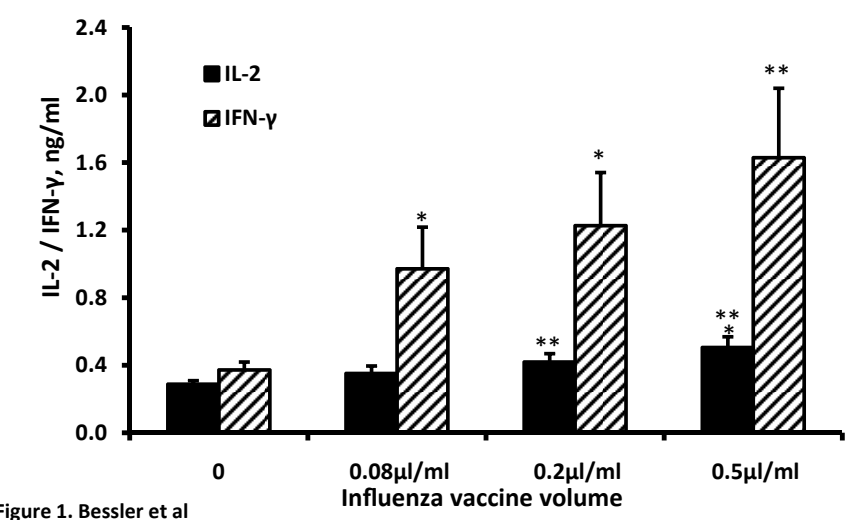

Figure 1. Effect of influenza vaccine on the secretion of IL- 2 and IFN- $\gamma$ by non-stimulated PBMC. 2x106 PBMC were incubated for $48 \mathrm{hrs}$ in the presence of influenza vaccine at volumes as indicated. The level of the cytokines in the supernatant was tested by ELISA. Each column represents the mean of 14 experiments. Bars represent SEM. Asterisks represent statistically significant difference from PBMC incubated without influenza vaccine $\left({ }^{*} \mathrm{p}<0.05 ; * * \mathrm{p}<0.01 ; * * \mathrm{p}<0.001\right)$. immune cells. IL-2 is a cytokine that plays a central role in immune response. It stimulates cellular as well as humoral reactivity. IL-2 stimulates $\mathrm{T}$ cell and NK cell proliferation, survival and activation in vitro [16]. Natural killer cells (NK) play an essential role in the immune response against influenza infection. NK cells secrete a variety of cytokines, IFN- $\gamma$ among them being particularly important since it initiates macrophages to kill phagocytized pathogens [17]. At the early stages following influenza infection NK cells contain viral replication obtained by killing of infected cells [18]. IL-2, affecting predominantly $\mathrm{T}$ cells, acts a pivotal factor in the immune defense against viral and other invaders. It has been shown that IL-2 regulates T-cell motility, adhesion properties and cell proliferation by enhancing the synthesis of the endogenous thrombospondin-1 [19]. According to Hua et al., [20] the concurrent activity of IL-2/IL-2 receptor alpha pathway induces expression of $\mathrm{CD}^{+} \mathrm{T}$ cells with cytotoxic potential against influenza viruses. In addition IL- 2 has been found to be essential in the optimal activation and survival of $\mathrm{CD} 4^{+}$and $\mathrm{CD} 8^{+} \mathrm{T}$ cells that contribute to the clearance of influenza virus during primary and secondary infection. This effect can be achieved either incases that the cytokine acts alone or concomitantly with IL-21 and IFN- $\gamma[21,22]$. During the H1N1 influenza outburst in 2009, Sridhar et al., [23] have observed that individuals with higher incidence of $\mathrm{CD}^{+} \mathrm{T}$ cells producing IFN- $\gamma$ and IL-2 showed better outcome after the infection. The occurrence of $\mathrm{CD}^{+} \mathrm{T}$ cells' expansion after influenza infection has been supported by another study [24]. Following $2009 \mathrm{H} 1 \mathrm{~N} 1$ influenza pandemic, Weaver et al., [25] have found that humans responded to the infection by a distinct expression of TNF- $\alpha$, IFN- $\gamma$ and IL- 2 producing CD4 ${ }^{+}$ $T$ cells observed one month post-infection. Considering the fact that $\mathrm{T}$ cells and particularly $\mathrm{CD} 4^{+}$cells are the primary target of viruses' attack in general, the observed in vitro increased production of IL-2 and IFN $\gamma$ by PBMC in the presents study underlines the importance of these cells in the resistance to influenza virus infection. However, it should be emphasized that immune cells of other types, such as $\mathrm{CD} 14^{+}$and $\mathrm{CD} 16^{+}$monocytes producing TNF- $\alpha$ and IL- 6 , have been found to increase in number following influenza vaccination [11]. In our hands, there was not alteration in the production of the proinflammatory cytokine IL-6, although according to Lauder et al., [26] it has been shown to exert anti-viral responses by modulation of T-cells function. Working with IL-6 deprived mice the authors have observed severe lung pathological changes in the animals concomitant with increased production of the pro-inflammatory cytokines IFN- $\alpha$ and TNF-a. Giamarellos-Bourboulis et al., [27] have examined TNF- $\alpha$, IL$1 \beta$ and IL- 6 concentrations of healthy volunteers at the beginning of signs of influenza A ([H1N1) infection, cases with flu-like syndrome and patients with H1N1 fully developed illness. While TNF- $\alpha$ and IL$1 \beta$ serum concentrations did not differ between the three groups, IL- 6 was found to be elevated in the individuals with flu-like syndrome. Conversely, human macrophages exposed to influenza H1N1 virus did not show increase of IL-1 $\beta$, TNF- $\alpha$ or IL-6 [6], as has been observed in the present work. One has to keep in mind that the capacity of the immune cells to produce pro-inflammatory cytokines following influenza virus infections depends conspicuously on the pathogen's virulence degree and on the viral load [28]. The increased production of IFN- $\gamma$ found in the present work is in line with other reports that have delineated that influenza A virus stimulated human macrophages to produce not only IFN- $\alpha / \beta$, but also a substantial number of inflammatory cytokines including IL-18, a cytokine capable to further induce IFN $\gamma$ expression $[9,29]$.

In short, the present work indicates that three viral strains integrated in a seasonal influenza vaccine recommended by the Health 
Authorities in this country promoted in vitro production of both IL-2 and IFN- $\gamma$, two cytokines pivotal for the antiviral defense of the organism.

\section{Author disclosure statement}

No competing financial interest exists. The authors declare that they have no competing interests. There were no funding sources for the study

\section{References}

1. Laidlaw BJ, Decman V, Ali MA, Abt MC, Wolf AI, et al., (2013) Cooperativity between $\mathrm{CD} 8+\mathrm{T}$ cells, non-neutralizing antibodies, and alveolar macrophages is important for heterosubtypic influenza virus immunity. PLoS Pathog 9: e1003207. [Crossref]

2. Altenburg AF, Rimmelzwaan GF, de Vries RD (2015) Virus-specific T cells as correlate of (cross-) protective immunity against influenza. Vaccine 33: 500-506. [Crossref]

3. Kreijtz JH, Fouchier RA, Rimmelzwaan GF (2011) Immune responses to influenza virus infection. Virus Res 162: 19-30. [Crossref]

4. Elhelu MA (1983) The role of macrophages in immunology. J Natl Med Assoc 75: 314-317. [Crossref]

5. Kajiya T, Orihara K, Hamasaki S, Oba R, Hirai H, et al., (2008) Toll-like receptor 2 expression level on monocytes in patients with viral infections: monitoring infection severity. J Infect 57: 249-59. [Crossref]

6. Nichols JE, Fitzgerald TF, Roberts NJ Jr (1993) Human macrophage responses to vaccine strains of influenza virus: synthesis of viral proteins, interleukin-1 beta, interleukin-6, tumour necrosis factor-alpha and interleukin-1 inhibitor. Vaccine 311: 36-42. [Crossref]

7. Wong JP, Christopher ME, Viswanathan S, Karpoff N, Dai X, et al., (2009) Activation of toll-like receptor signaling pathway for protection against influenza virus infection. Vaccine 27: 3481-3483. [Crossref]

8. Julkunen I, Melén K, Nyqvist M, Pirhonen J, Sareneva T, et al., (2000) Inflammatory responses in influenza A virus infection. Vaccine 19 Suppl 1: S32-37. [Crossref]

9. Julkunen I, Sareneva T, Pirhonen J, Ronni T, Melén K, et al., (2001) Molecular pathogenesis of influenza A virus infection and virus-induced regulation of cytokine gene expression. Cytokine Growth Factor Rev 12:171-80. [Crossref]

10. Roberts NJ Jr, Prill AH, Mann TN (1986) Interleukin 1 and interleukin 1 inhibitor production by human macrophages exposed to influenza virus or respiratory syncytial virus. Respiratory syncytial virus is a potent inducer of inhibitor activity. $J$ Exp Med 163: 511-519. [Crossref]

11. Mohanty S, Joshi SR, Ueda I, Wilson J, Blevins T, et al., (2014) Prolonged ProInflammatory Cytokine Production in Monocytes Following Influenza Vaccination is Modulated by IL-10 in Older Adults. J Infect Dis 211(7):1174-84. [Crossref]

12. Hoeve MA, Nash AA, Jackson D, Randall RE, Dransfield I (2012) Influenza virus A infection of human monocyte and macrophage subpopulations reveals increased susceptibility associated with cell differentiation. PLoS One 7:e29443. [Crossref]

13. Merekoulias G, Alexopoulos EC, Belezos T, Panagiotopoulou E, Jelastopulu DM (2010) Lymphocyte to monocyte ratio as a screening tool for influenza. PLoS Curr 2: RRN1154. [Crossref]
14. Cao W, Taylor AK, Biber RE, Davis WG, Kim JH, et al., (2012) Rapid differentiation of monocytes into type I IFN-producing myeloid dendritic cells as an antiviral strategy against influenza virus infection. J Immunol 189:2257-65. [Crossref]

15. Hou W, Gibbs JS, Lu X, Brooke CB, Roy D, et al., (2012) Viral infection triggers rapid differentiation of human blood monocytes into dendritic cells. Blood 119: 3128-3131. [Crossref]

16. Wang Y, Zheng X, Wei H, Sun R, Tian Z (2008) Different roles of IL-15 from IL-2 in differentiation and activation of human $\mathrm{CD} 3+\mathrm{CD} 56+$ NKT-like cells from cord blood in long term culture. Int Immunopharmacol 8: 927-934. [Crossref]

17. Kubota A, Lian RH, Lohwasser S, Salcedo M, Takei F (1999) IFN-gamma production and cytotoxicity of IL-2-activated murine NK cells are differentially regulated by $\mathrm{MHC}$ class I molecules. J Immunol 163:6488-93. [Crossref]

18. Schultz-Cherry S (2015) Role of NK cells in influenza infection. Curr Top Microbiol Immunol 386: 109-120. [Crossref]

19. Bergström SE, Bergdahl E, Sundqvist KG (2013) A cytokine-controlled mechanism for integrated regulation of T-lymphocyte motility, adhesion and activation. Immunology 140: 441-55. [Crossref]

20. Hua L, Yao S, Pham D, Jiang L, Wright J, et al., (2013) Cytokine-dependent induction of CD4+ T cells with cytotoxic potential during influenza virus infection. $J$ Virol 87: 1184-1193. [Crossref]

21. Khattar M, Miyahara Y, Schroder PM, Xie A, Chen W, et al., (2014) Interleukin-21 is a critical regulator of CD4 and CD8 T cell survival during priming under Interleukin-2 deprivation conditions. PLoS One 9: e85882. [Crossref]

22. Li J, Arévalo MT, Chen Y, Chen S, Zeng M (2014) T-cell-mediated cross-strain protective immunity elicited by prime-boost vaccination with a live attenuated influenza vaccine. Int J Infect Dis 27: 37-43. [Crossref]

23. Sridhar S, Begom S, Bermingham A, Hoschler K, Adamson W, et al., (2013) Cellular immune correlates of protection against symptomatic pandemic influenza. Nat Med 19: 1305-1312. [Crossref]

24. Sckisel GD, Tietze JK, Zamora AE, Hsiao HH, Priest SO, et al, (2014) Influenza infection results in local expansion of memory $\operatorname{CD} 8(+)$ T cells with antigen nonspecific phenotype and function. Clin Exp Immunol 175: 79-91. [Crossref]

25. Weaver JM, Yang H, Roumanes D, Lee FE, Wu H, et al, (2013) Increase in $\operatorname{IFNI}^{3}(-)$ $\mathrm{IL}-2(+)$ cells in recent human CD4 T cell responses to 2009 pandemic H1N1 influenza. PLoS One 8: e57275. [Crossref]

26. Lauder SN, Jones E, Smart K, Bloom A, Williams AS, et al., (2013) Interleukin-6 limits influenza-induced inflammation and protects against fatal lung pathology. Eur J Immunol 43: 2613-2625. [Crossref]

27. Giamarellos-Bourboulis EJ, Raftogiannis M, Antonopoulou A, Baziaka F, Koutoukas $\mathrm{P}$, et al., (2009) Effect of the novel influenza A (H1N1) virus in the human immune system. PLoS One 4: e8393. [Crossref]

28. Geiler J, Michaelis M, Sithisarn P, Cinatl J Jr (2011) Comparison of pro-inflammatory cytokine expression and cellular signal transduction in human macrophages infected with different influenza A viruses. Med Microbiol Immunol 200: 53-60. [Crossref]

29. Sareneva T, Matikainen S, Kurimoto M, Julkunen I (1998) Influenza A virus-induced IFN-alpha/beta and IL-18 synergistically enhance IFN-gamma gene expression in human T cells. J Immunol 160: 6032-6038. [Crossref]

Copyright: (C2016 Bessler H. This is an open-access article distributed under the terms of the Creative Commons Attribution License, which permits unrestricted use, distribution, and reproduction in any medium, provided the original author and source are credited. 